\title{
Ethnocultural Features of Culture Game Elements
}

\section{Seraly Shabayevich Tleubayev}

Doctor of Philosophy, Professor, Regional Socio-Innovative University Email: bal_67@list.ru

\section{Balzhan Seidramanovna Tleubayeva}

Ph.D., Assistant Professor, M. O. Auezov South Kazakhstan University Email: tleubayev63@list.ru

Yulduz Azimkhanovna Saparova Ph.D., Assistant Professor, M. O. Auezov South Kazakhstan University Email: ylduz58@bk.ru

\section{Gulnar Zhumagaliyevna Shagitova}

Lecturer, M. O. Auezov South Kazakhstan University Email: g.shagitova@mail.ru

Ainur Abdrakhmanovna Zhienbekova

Ph.D., Assistant Professor, M. O. Auezov South Kazakhstan University Email: Ainur-7171@mail.ru

Nasipkhanim Kamalkhyzy Kamalova

Ph.D., Assistant Professor, M. O. Auezov South Kazakhstan University Email: n.kamalova-46@mail.ru

\section{Doi:10.5901/mjss.2015.v6n1s2p9}

Abstract

The attention to influences of specifically ethnic cultures on the forms and the maintenance of games is given in article. The problem of an interethnic exchange of game's practices and updating of these practices in other ethnocultural context is put. So we brought the Soviet power tried to take under control the traditional folk festivals, amusement and games approved on the territory of the Russian Empire, carrying out so-called Cultural Revolution. First of all, the government has sought to impose a ban on the games, which is in one form or another, and were related to the religious life of the people. Soviet power, therefore, sought to maximize ideologies game and force them to serve the regime.

Keywords: ethnocultural; ethnic groups; folk festivals; culture game elements; Cultural Revolution;

Any phenomenon of culture is not only cultural and historical, but also is ethnocultural. This article is devoted to the given aspect of this phenomenon. Of course, here we are faced with the problem which are still debated one of the essence of ethnic. But we are not going to cease on it.We only note the basic concepts of ethnicity today are: 1) primordialistic, 2) instrumentalistic and 3) constructivistic concepts (Sadokhin A.P., 2000). We accept thatinterpretation , which belongs to M. Boroday (Boroday Yu. M., 1996). According to him, Ethnics is pre-national socio-cultural education, regardless of whether it has its own their statehood or not. And if it doesn't have, then it is should not be regarded as underdeveloped nation and its culture. Ethnic groups differ significantlywith large differences in cultures rather than in nations. In relation to our subject, itmeans that games will have ethnic and cultural characteristicswhile retainingthe general essential features ofgame phenomenon and eventhe presence ofthe sametypes of specificgames incultureof 
each more or lessdistinctiveethnics. We will consider a number of ethnic groups and cultured games in them. I. U. Sambu , ethnic Tuvan, has researched traditional Tuvan folk games which is one of the Turkic ethnic groups and at the same time closely connected with the Mongolian ethnic group . Like other ethnic groups, many games were confined to Tuva holidays. Samba is allocated by New Year's holiday ( Shagaa) and Youth Day ( oytulaash ). These festivals, especially the "Shagaa" has the seal of religiosity. Shamanism was traditional religion of Tuvan, as well as of other nation'sin this area. When Lamaism formed inTibet came from Mongolia (synthesis of Mahayana Buddhism and local religion), and then it also has put its seal on the flow and passing of holidays. Nevertheless, Shamanism and Lamaism openly coexisted until the establishment of Soviet power.

I. U. Sambu writes: " InTuvathe content of holidays for differentlayersof the nation was not the same. Games and celebrations were the main elements of holidays for common people, prayer was the main subject for clergy. Shamans and lamas perform a prayer for three days before the New Year : Lamas read holy books and prayer, sacrificed, prayed for a happy new year and prosperity of Yellow Faith ( sharain, shazhin - Lamaism ), and shamans contacted with spirits ( evil and good ) in the same sacramentation(ritual), "made an agreement " about happy new year, people asked to bestow prosperity , to their families and cattle "(Sambu I.U., 1978). During the holiday "Shagaa" were held the fights and jumping, i.e.the conceptions 'activity' that is being developed in this article are not games.

I.U.Sambu writes: " Oytulaash is not only and not so mysterious meetings ... and nota manifestation of freedom of premarital sexual relations ( according to G. Kurbatsky ) but it is a traditional youth game, which defines the mutual relations between the youth. Oytulaashis the common name for night games ... The content of Oytulaashis extremely rich and it has a certain internal system, although, undoubtedly, it was played in different ways in different regions, as oytulaash is not formulaic game, but it has creative character"(Sambu I.U., 1978). I.U.Sambudescribes the holiday oytulaash in the following way "On a fixed day, September the 15th of the lunar calendar (full moon), young people gather at some beforehand chosen grassland. Participants came mostly from neighbouringvillages riding a horse, a bull or came on foot. Elect the leader one. If he managed to rule the group or people well , he will be left for next game. The game elements of oytulaash were: Chinchichazhyrar( to hide beads) , arzhyylKagari ( handkerchief game ), okchygyrtyr ( shoot arrows ), etc. A great placeis allottednight game ak-yyash (white stick), bertKagar ( in caps ), jumps on bullswithout a saddlein the moonlight "( Sambu I.U., 1978). In so far as the author does not decrypt the content of these phenomena, so it remains to believe that they are all games.

Besides these games, which are associated with two major holidays, Tuvinianshas plenty ofother games. I.U.Sambu divides them into four groups: 1 ) massive folk games ( bug Kagari) [belt knocking],bug Adari [ archery into belt], kara Adar [ archery into target ], at charyshtyrary [ horse race ], hyresh [ national fight ], margyldaalygoyunnar [ game -competitions] ); 2) tabletop family and household games ( shydyraa [ playing chess ], Buga - shydyraa [bullish chess],Tugulym - shydyraa [ veal chess ], horul - Oinu [horul game], Daala , panchyk, kazhyk [bones game ], dert Berge [ four difficulties "game for good luck"], ChyttyrypKagari [dice game], duzhurupKagari, at tudary [to catch a horse], aattudaroyun [to catch a horse ], kazhyk - Bile bodalazhyry [ dice game " oralaccount"], kazhyk Bileaatcharyshtyrary [ jumping], kazhyk Adar [ shooting into the dice] ); 3) Youth Games ( hynyn yry [round dance ],ak - yyash [ white steak], sogur -aza [ blind heck], ok chugurturu [passing arrows ], Chinchichazhyrary [ find beads],tevekteeri [ pochekushki ], myngyrty [teeterboard ], chumgu [ skating ], adyr but [contest on stilts ], kuuylu [game with a stick ]); 4 ) children's games and adults games with children ( sayzanaktaary [ gameaal], Ujar - ushpas [ fly- not fly], chashtyry [hide], bodalgalazhyry [ oral account], sound and imitative play (drum, hirleesh buzzer ), games on fingers ( game thread, chylgychylar [ herdsmen ] Ceadir [ hut ], Aldynordu [ golden palace ] ), adult games with children ( bep - bep [ stop stop] , tep-tep [put on , put on], Arbaihoorar [ roast a barley ], davyyry [ rider], kichik - kichik [tickling],dumchuktudar [ catch a nose ], play with their fists ).

It is easy to notice that the author has included to the list of games not only which are in his proper sense , but also no game-contests and just kinds of entertainments. He , as was noted above , highlighted the "game - contests" ( margyldaalygoyunnar ). What does he refer to them ? He classifies 1) Charynshavylaary (" break a blade " : is meant the ram scapula), 2 ) hendirbesygar (" break the back " for example, of cow ) and 3) Moyun - oorar ("disassemble the the cervical vertebrae "). Indeed they are kinds of competitions, but not kinds of games. Relatively adults games with children , they are, of course, games, but for children under the age of 2 or 3year old. For example, the author describes the game with the fists as following: " Pinch fist left hand fist with the palm up, and his right hand palm is substituted so that the fingertips touch the part of the little finger of his left hand clutched fist. Then by counting one, two changes the hand actions "( Sambu I.U., 1978).

Academician V.A.Gordlevskyhas conducted a research work with the Anatolian Turks games. He anticipates the result of his research in the following consideration: " People always look for fun and pleasure in games. For a child it is the only purpose of life; and for older person game is a holiday during the work, it detracts people from black thoughts 
and makes replenishment to exhausted and fatiguedforces. Game eliminates all the unpleasant things consciously, which accompanies the labor; labor during the game, and during this progress interests and ideas changes into fun and amusement. Game it is a real fun, laugh, and the interest is continuously supported by the fact that one side is a loser and , therefore, a triumph is destined to winner , he will enjoy the humiliation of the unfortunate loser and will rejoice " (Gordlevsky V.A., 1968).

His friends Nouri were his informants, who was born in Ayyash ( from region Ankar) , and Ahmed, who was born in Karahisar (region Sivas) .On the basis of compared information which are obtained from them V.A.Gordlevsky concludes: "Ankarian games ara rude, but they are original and they are better to reveal the people's environment (and sometimes as if its ethnographic compound conglomerate); Sivas Games are softer, and this this is the game for urban, often for children, games in which were erased the features of individualism " (Gordlevsky V.A., 1968). The last note seems to bestrange :but individualism is a product of the very late epoch. Speaking of those games, about which he learned from his informants, V.A. Gordlevsky makes a note: " The stock of folk entertainment is not confined with them of course, but they characterize some range of human age, sex, environment, etc.; here are alsoparlour games, and field games; games for women ( the number of which,undoubtedly would be more if I wrote down them from women ); parlour games take place especially in the winter when people are especially at home because of the cold. Social games that accompany wedding parties( pahlavans struggle, racing, polo and etc.) require a space for being taken place. " (Gordlevsky V.A., 1968).

V.A.Gordlevsky highlights and describes 13 types of the Anatolian Turks games, each of which covers a variety of specific games : 1) imagination games

(Haji Baba , Abbar -Jabbar , solelschik, game in prisoners(captives) ' roomie, my roomie , insensible my roomie "," Kesem ", kitten, wolf and sheep , the chief of the caravan or the bride, " Alaylar , kalaylar " jumping on one leg, " Lechuk "); 2)Babky( Granny) (" granny,lebbik , tombak ); 3) Tura (" Do not put back! " The fish dived) ; 4 ) Ball ( ball , ball [ gyudyul ] ); 5) Chizhik ( Chelik ) (chizhik, chizhik water [ suCheliyi], syuldyur, Hurle -Turle, chortu, shepherd's stick [chobanDeinei ]); 6 ) Arrows; 7) Fights ( basket-uncle [ sepetchidayy ] war without arms, just with legs ); 8) blindfold (" Guess Who has hit " charykipine-tree [ cham -chamchari ] , " Tr -r tr-r "); Pragane ( ra-a-az. .. [ bir-dir-bir ...], catching the gripe patties on a donkey, long donkey [ Uzuneshek ], hot baths vault ); 10) Hidden (hidden [ kozyumudzhu ], goat, bluebit, "Hide , my sister [ Saklan , Budgy ] !") 11) Touching with hand ( "Look at my slender growth ! " Gyudyu - gyudyu ! ) 12 ) Ring ( ring game [ YuzyukOinu ] ); 13 ) Rough mockery (outrunning [gemche]) (Gordlevsky V.A., 1968). The latest of these games is concluded as following. " Some boy convinces other ones to run a race , promising to give something back to the one who beat him. When someone will be ahead of all, he laughs at them, saying: "Onyude-kedyue, arttakibua , " Poor boys , seeing that no matter where they are, all will laugh at them ,and so they refuse to run anymore ; they realize that they have been deceived " (Gordlevsky V.A., 1968). Not all of the above described 'games' by V.A.Gordlevsky are really games. But he himself also understands it in some extent. In particular, he remarks : "Often, it is a sport ( such as grandmother, ball, throwing darts, etc.), which develops muscles or agility and quickness ; or is it an idea that plays real life , sometimes present lifesometimes dead and preserved only in some kind of remnants (gameaction or game- song) " (Gordlevsky V.A., 1968).

Describing the game in the Kyrgyz culture , S.M. Abramson writes, "Games differfor the youth, for men(male) and children's. The most common among youth games are jooluktashtamai (similar to Russian game " zhgut ") dympyldek game "Wolves and Sheep", zhashynbak - peekaboo, different kinds of games in hide and seek. One of the favorite entertainment of youth is a swing ( selkinchek ) on ropes tied to trees or poles. Sway in twos, with singing. Among themale youth games the ball game should be noted(karakazan), which has some similarities with football ,orompoy play catch-up on one leg, koonyzmey -it is a game that the two groups holding hands on pull an another one , akche日lmek - night game, during the which the two parties compete to find out and deliver thrown bones or white ball of wool to the place before the cusp.

Favorite game is men contest arkantartysh (pulling the rope), but knuckles are very popular among them (ordo), which reproduces the battle to capture the rate of khan.

Of the most popular children's game is Chiquita - chizhik game, different kinds of games in the headstock , esheksekirtmey - a game similar to Russian leapfrog(cheharde), ala kychyk - a game of "cat and mouse" (Abramson S.M., 1963).

D. Omurzakov distinguishes the differences between Kyrgyz national sports (of course, it is not a sport in the real sense of thisconcept ) and Kyrgyz folk games, but in his pamphlet he found it possible to give them a description in an alphabetical order (Omurzakov D., 1958). Therefore, games are still mentioned (for example, youth game ak - cholmok [white shuttle ]) and competitions (for example, at-chabysh [ racing ]), and even types of hunting (burkutchi [ hunting with an eagle]). G.N. Simakov, another researcher of Kyrgyz games culture, considers the conception entertainment more 
general relatively to the concept of the game. He, in particular, had written: " All the children's entertainment we divide into two major categories: fun and games that promote the spiritual development of a child, and entertainment, which is directed to his physical education. However, heprécises, almost in every child's play or fun , as a rule, there are elements of both spiritual and physical education " (Simakov G.N., 1984). In his another work G.N.Simakov writes: "Kyrgyz national entertainment ( games, popular sports and entertainment ) are the integral part of the cultural heritage of the people" (Simakov G.N., 1980). In brackets, we note that fun and entertainment are close and even related phenomena, but not identical.

At the end of this article we turn to the traditional Kazakh culture, to a culture of Kazakh ethnos and to those games that have been formed in this culture .It is not significant for this article that the ethnos "kazakh"(qazaq) became known in this or that historical period.Taking into account the lifestyle of nomads who inhabited the arid zone of modern Kazakhstan, along many centuries they remained unchangeable, then it is obvious, that those were the people who are in a relatively late written sources appear under indicatedethnonym. Therefore, in this paper we will not distinguish the differences between the " protokazakhs " and actually " Kazakhs " as inappropriate for him.

In traditional Kazakh culture, as in any other culture existed games that were closely associated with all sorts of festivities ( social , family, and others). The biggest holiday is Nauriz, which is held on the vernal equinox, and which is considered to be the beginning of a New Year. Games in these festivals are very closely intertwined with all sorts of entertainment, including a controversial character. They are not often only in ordinary consciousness, but also in the researchers' minds are identified with the games. "'" "In a view of the nomadic lifeway of the Kazakhs - said A.B. Kalyshev - the most widespread got the horseracing and all sorts of games on horseback ... Veneration of horses and love to horses Equestrian Games have become a tradition, preserved until nowadays " (Kalyshev A.B., 1995). V.V.Vostrov and I.V.Zakharovhas written " The most popular and widespread types of sport were skachki - bayga ( bəyge ). There were two kinds of races ; endurance ( alaman bəyge ), which is conducted over long distances (up to $100 \mathrm{~km}$ ) and simple bayge - at a distance of $5-10 \mathrm{~km}$. Race took place normally on rugged terrain, with lots of essential obstacles and therefore demanded that the horse and rider to have a lot of physical strength, endurance and proficiency " (Vostrov V.V., Zakharova I.V., 1993). Of course, it is not a sport in its ownsense, but also is not a game, but simply a match. Certainly, it was a spectacular event. "Two combat horsemen dzhigits (audaryspak) attracted the attention of a large amount of spectators" wrote thequotated authors, each of which sought to throw the enemy out of the saddle . Equestrian sports contest - kokparwas one of the most widespread and popular entertainment of the Kazakh people . Its members sought to wrest from each other goat carcass and deliver it to the judges . Two parties could take part in it, or there was a struggle for the individual championship .

Very interesting and original game was a horse game (kyzkuu) .A girl on a frisky horse, who is very brisk and dashing rider went out in the circle and with jokes and ridicule egged dzhigits, and often " regaled " their lashes. Any of dzhigitscould not stand and jumped on his horse, and began pursuing the girl. It was considered shameful for dzhigit, if he could not catch her. Also were arranged competitions for lifting off the ground at full gallop coins ( TENGE alu or kymis alu), dzhigitovka ( zhigit zharys ) , as well as a shooting competition at the target (Altynkabak); best shots (Mergen) often received major awards.

Folk strongmen also were of great popularity among Kazakhs (paluan), competed in wrestling (kyres). This kind of national sport is very close to wrestling " (Vostrov V.V., Zakharova I.V., 1993). It is easy to notice that the authors having no clear criteria to distinguish the game from a non- game, in this case, from the usual, and even though implemented in the form of entertainment from the contest. And, of course, as already was noted above, there is no place to talk about sports.From these abovementioned ones for the game can be attributed only kyzkuu,kokpar and more . "Kazakhshad a lot of guys and mass games in the past" wrote V.V.Vostrov and I.V.Zakharov. The most popular of these were togyz kymalak, kek bori( gray wolf ), kyzbori (wolf - girl), belbeusokty (strike zone), tori bies (bay mare ),sokyrTeke (blind goat) , in which played both adults and children at festivals and just in a spare time " (Vostrov V.V., Zakharova I.V., 1993). A.B.Kalyshev classifies the games sayys-riders combat on the spears. He describes it as following: "The strugglers for the fight were exposed from different genera or between neighboring nations, such as between Kazakhs and Kyrgyz in the south of Kazakhstan . Participants were fitted with the necessary gear and armed with long wooden spears with a blunt end. The purpose of the fight is to knock the opponent out of the saddle or to inflict a heavy blow that he could not continue the combat. Often there were deaths and glowing passion led to serious collisions between births. Subsequently, this game was banned by imperial administration " (Kalyshev A.B., 1995). It is unlikely that this event resembling thegladiators fight in Ancient Rome, can be considered as a game. Meanwhile M. Gunnar and M. Rahimgulov find it possible to say, "Sayys is extremely interesting and one of favorite kinds of equestrian sport" (Gunnar M., Rahimgulov. M., 1994).

M. Tanikeev along withsayys also says about tuie-sheshu( unleashing the camel). It isa very specific type of 
competition ,in which attendedthe poor , and the audience was rich. M. Tanikeev describes it :" "Contest " was held in the following way.Camels with various goods are brought to large circle surrounded by the audience. The participants could only be people of different sexes, who had to go into the circle completely naked. If they managed to untie the bound feetof camelwith teeth and take him outside the circle, all jewelry together with a camel will be their property " (Tanikeev M., 1975). This form of competition , as the previous one,can not be considered as a game for any reason. Game in its essence does not assume the humiliation of agonists' human dignity and abuse.

There were also specified children's games among Kazakh nationality. " The most favorite games were alychki ( asyk )" said A.B. Kalyshev - painted sheep. Youth and adults were sometimes the players of this game too . There are numerous options. The most prominents were alshy ,Onka Khan bestas, atbakyl, zhyirmabir etc. Played also hide and seek ( zhasyrynbak, sokyrteke,sokyrsiyr), solved the riddles ( myrysh - myrysh , tuye-tuye). The same character had kind of game in a lapta (ordadop), in shizhiki(kazan orordashyldik) " ( Kalyshev A.B., 1995). Among the games of intellectual order Kalyshev A.B. and V.V.Vostrov and I. Zakharova highlights the table game togizkumalak(nine pellets) . Kalyshev gives the following description of it: "Rectangular wooden board was used for this game, which has 18 oblong holes (otau), disposed in two rows of nine in each row. Between the rows there are carved two more big holes of round shape (kazan) . Each player (two of them ) have by 81balls, and place by nine into holes. Movements are made turn by turn. The winner is the one who picked upmore balls from the opponents hole into hiskazan. The game was so popular that it could dispense with the board. To do this, participants needed to dug a hole on the ground and there they held the party" (Kalyshev A.B., 1995).

A large spread in Kazakh life got sort of dance game " kusbegi - dauylpaz " - learning an eagle , "Koyan - berkut " - eagle's hunting to the hare, which were created and existed among the people, constantly being improved and transformed, on the basis of rethought symbolic content of ritual acts in an illusory form recreating work skills of hunter in training to hunt a bird.

In a result of rethought of ritual - magical ceremonies of pastoralists - nomadics, was emerged Kazakh popular dance game "Or Teke", which humorously transmits the motion and unexpected jumps of a kid.

Soviet power tried to takeunder control the traditional folk festivals, amusement and gamesapproved on the territory of the Russian Empire, carrying out so-called "cultural revolution" . First of all, the government has sought to impose a ban on the games, which is in one form or another, and were related to the religious life of the people. Soviet power, therefore, sought to maximize ideologize game and force them to serve the regime. Also, of course, invent new , specifically "socialist" game. But that's a topic for another article.

\section{References}

Abramson S.M. (1963). Kirghiz / Peoples of Central Asia and Kazakhstan. T. II. Moscow: Academy of Sciences of the USSR. Boroday Yu. M. (1996). Erotica - death - taboo: the tragedy of the human consciousness.

Gordlevsky V.A. (1968). Games of Anatolian Turks / Selected Writings. T. IV. Ethnography, History of Oriental Studies, reviews.

Gunnar M., Rahimgulov. M. (1994). Digestof the Kazakh people's national sports. Alma- Ata.

Kalyshev A.B. (1995). Folk festivals and games /Kazakhs. Historical and ethnographic research. Almaty.

Omurzakov D. (1958). Kyrgyz national sports and folk games. Frunze.

.Sadokhin A.P. (2000). Ethnology.

Sambu I.U. (1978). Tuvan folk games . Historical and ethnographic study. Kyzyl.

Simakov G.N. (1984). Social Functions of Kyrgyz folk entertainment in the late XIX - early XX century. Historicaland-ethnographic essays.

Simakov G.N. (1980). Soviet Kyrgyz national holidays and entertainment/ Ethnographic aspects of the study of modernity.

Tanikeev M. ( 1975) . Kazakh national sports and games. Alma- Ata.

Vostrov V.V., Zakharova I.V. (1993). Public and family life / The peoples of Central Asia and Kazakhstan. T. II.. 